\title{
The Poetics of social work - how being artful in our craft takes us elsewhere into mindfulness
}

\author{
Vaughan Milner
}

\section{Abstract}

Poetry is an ageless craft that helps people find meaning and gives hope and courage. The poetics of social work describes an evolving framework in which poetry is located as a knowledge base that draws out mindfulness in the midst of uncertainty. Examples are provided of how the spiritual and artful aspects of the social work craft can be made more purposeful and explained through a poetic frame. Notions of light, time and space contextualise the way authentic relationships are at the heart of our work.

Many people talk about the art of social work, often in the context of the more mysterious, intangible, and less 'scientific ' aspects of our craft. Usually such references are around the relational intimacies that our work relies on to be effective. In essence this is the connection between people, and the possibilities and hope that emerge from that authentic helping relationship.

An alternative view would be that describing social work as an 'art' places the work in a romanticised and nonsensical frame from an era before professionalisation, and the framing of practice in theory, defined skills and qualifications.

The professionalisation of social work has certainly meant 'more than common sense' (Maidment and Egan, 2004) is expected in the application of theory and practice. This begs the question of the artfulness of practice. These notions of the art and craft of social work deserve exploration.

\section{Poetry and social work}

The search for knowledge has diverse pathways. To a large extent social work knowledge is taught from academic disciplines such as psychology and sociology, and theoretical and clinical bases like ecological systems theory or narrative.

I consider there is merit in also drawing from the spiritual and metaphysical literature and knowledge that falls back into soul, culture, and history. In this sense poetry has a contribution to make.

The poet Howard Nemerov (1977) in the epic memorial The Painter Dreaming in the Scholar's House writes of: 
... spinning relation out ... Weaving its fabric up, so that it speaks darkly, as music does. Singing the secret history of the mind ... Finding and faithfully reflecting the mindfulness that is

in things and not the things themselves.

Nemerov goes on to talk of 'art as an act of faith' and that in its practice 'there shines a happiness through darkest themes As though spirit and sense were not at odds.'

I have previously explored what I described as uncommonly sensible social work practice where we match what we know with what we sense (Milner, 2006). By using the poetics of social work we can step further into mindfulness, which is the ultimate dimension of reflective practice, in Nemerov's terms the 'light that is in thought'.

This notion of light in thought, and spirit and sense not being at odds, can additionally be framed as a reference to the hopefulness that comes through sense making. Where sense making is artful, it enables the spirit of creativity to emerge when workers and clients dwell in what is possible. The thin space between hope and despair is fertile ground for mindful inspiration.

Good poetry is uplifting. As New Zealand poet Michael Harlow (2009a) says 'poetry is when words sing.' The poetics of social work provide a rich vein of imaginative and exhilarating pathways that bring hearts and minds together in praxis focused on the mystery of life. Using poetry as a point of reference does no harm, and in some situations is as essential to the small steps of social work as more conventional practice skills.

\section{The Winged Energy of Delight (Rilke, 1981a)}

One of the critical challenges for any social worker is to empower those they work with. Empowerment has many definitions but its core is the act of enabling people to step out of themselves and their situations in a healthy and independent way. This requires imagination, grace, and the power of spirit that lifts you beyond the ordinary sense of things. Hart Crane (1933) captures this in Voyages II with the lines:

... Bind us in time, $\mathrm{O}$ seasons clear and awe. O minstrel galleons of Carib fire, Bequeath us to no earthly shore until is answered in the vortex of our grave the seal's wide spindrift gaze toward paradise.'

Of course getting to a point of empowerment and being able to look hopefully beyond the situation is no easy task. The relationship with the worker has to be right and the person themself has to be ready or at a point of openness. This is because the troubles that bring people to social workers, or us to them, are often gritty and deeply etched in life's shadows. An expectation of fixing the problem denies the reality that some things cannot be fixed but can be contained, made more bearable, or inched through. It is in this working through and wrestling with things that sense making occurs. More sense and a better understanding emerge hand in hand with inspiration 'so we are grasped by what we cannot grasp; it has its inner light, even from a distance - and changes us' (Rilke, 1981b).

This takes us back to art being an act of faith. If there is one article of faith in the social worker's art it must be a dogged belief in humanity and the capacity that everyone has to be, 'in the good sense of the word, good' (Machado, 1983). Sometimes establishing the rela- 
tionship between worker and the person that allows goodness to emerge is a battleground, especially in statutory services. Where the social worker has responsibilities to impose social control and to manage risk, or, where there is resistance, inherent relationship tensions and weary or wary cynicism can prevail. William Stafford (1977) cautions against this:

... if you don't know the kind of person I am and I don't know the kind of person you are a pattern that others made may prevail in the world and following the wrong god home we may miss our star.

Similarly organisations can unknowingly systematise a 'them and us' or group think dimension as a protection for workers and their tasks. This protective system then subtly disables anti-oppressive or empowerment activity.

I have formed a view over the years that artful practitioners find their own way through this and create relationships that matter, even in difficult and demanding situations. A key to this is recognition that we have to come to terms with, and live with, the elemental forces in our lives - the bright and the shadow sides. 'Look for your other half who always walks next to you and tends to be who you aren't' (Machado, 1983).

Critically reflective practice enables practitioner self -knowledge and a purposeful rather than defensive approach to the difficult. These in turn support a faithful approach to empowerment. In Rilke's (1981b) words' - just as the winged energy of delight carried you over many chasms early on, now raise the daringly imagined arch holding up the astounding bridges ... take your well disciplined strengths and stretch them between two opposing poles'.

\section{Being with and making space with people}

'We live in a world of motion and distance' (Jacottett, 1987). A pervasive comment on our times is the fast pace of life in a globalised, economically driven world. Many poets and social commentators reflect these themes and lament that we live in impoverished emotional and spiritual times and that people are increasingly distant from one another. Clients of social services frequently arrive searching for meaning and purpose amidst the significant distractions of ageing, unemployment, poverty, or violent and disintegrating relationships.

While these are real issues I am concerned that our profession underplays and ignores the criticality of life needing to be meaningful; that sense making is central to well being; and that place and space are important to cohesion and integrity in life. Perhaps if we paid more attention to these things some of the issues we are asked to 'fix' will be eased and easier.

To grapple with meaning and purpose we have to take a step into the unknown and the complexities of what Stephanie Dowrick (2009) describes as irrational truths. This is the stuff of the soul and the 'uncommonly sensible' spiritual side of our work.

The inner world of meaning, of how we understand our place and space relies on imagination, intuition and openness to voyaging in the depths of heart and mind. Harlow writes in Pensioners (1985): 'I have seen them stand and look through the immense distances of the heart ... inside their eyes there are planets spinning out of sight; born to see, they watch out.' As workers we experience this distance, and accompanying silence, that steps the day-to- 
day reality to a new depth of meaningfulness, through supervision and reflective practice. Pursuing parallel or similar ways of being in the moment with clients enables their search for meaning to be drawn out artfully. The faith of counsellors is predicated on this intimate engagement but there is more of a challenge in how social workers can achieve it.

The key lies in active and authentic engagement in the sense that doing things, being active with clients, nurtures and strengthens the relationship. Social work relies on the worker doing what has been agreed responsibly. There is then usually a point in time where trust and security, the connection of relationship, sparks change.

As important as the active and authentic worker/ client relationship is, connectedness to others is even more important. Regrettably this is often overlooked in our absorption with our role's responsibilities and expectations over what we might achieve. 'Despite 10 years of 'talking cure' twice weekly, such intimate conversation between strangers, he remains quite convinced that he is still, you know a tyger' (Harlow, 2005).

We need to challenge ourselves to look beyond this relationship we have with clients to the outer space of the client and what or who occupies that space. This is because one of the critical tasks of social work in the social justice sphere is to ensure people are connected to those around them. Professionals come and go. Attention is needed to the person in their space and others who are, or might be, part of the space in an enduring way. Increasingly in a world of distanced communities, social workers have a duty to satisfy themselves that people have others to turn to. People they love who love them back. 'Places we love only exist through us, space destroyed is only illusion in the constancy of time, places we love we can never leave, places we love together, together, together' (Lalic, 1996). The real meaning of space we love together is the depth of relationships and the network of social support that ensures social inclusion. This meaningful space together with place provides purpose and belonging.

A reflection by Edith Sodergran (1981) portrays ideas of patiently searching, of 'walking', being and doing until a connection with 'other restless hearts' brings recognition of interdependence and the hope that gives of something better.

... on foot I had to walk through the solar systems before I found the first thread of my red dress. Already I sense myself. Somewhere in space hangs my heart, sparks fly from it, shaking the air to other restless hearts.

Billy Collins (1998) provides a very active example of Shovelling snow with Buddha:

... but here we are working our way down the driveway one shovelful at a time. We toss the light powder into the clear air. We feel the cold mist on our faces. And with every heave we disappear and become lost to each other ... this is so much better than a sermon in church, I say out loud, but Buddha keeps on shovelling.

The silt shovellers of the recent Christchurch earthquakes will identify with this, and with the sense of community that shared activity brings.

Ginger Andrews (2004) also pursues the idea of action 'the cure for the mulleygrubs, she tells my sister, is to get up and bake a cake. If that doesn't do it, put on a red dress.' 
Robert Bly (1981) depicts the power of relationship in action in the poem For my son Noah, ten years old.

And slowly the kind man comes closer, loses his rage and sits down at the table ... when you sit drawing or making books, stapled with messages to the world ... or coloring a man with fire coming out his hair ... so we pass our time together, calm and delighted.

These verses and many like them, emphasise the connectedness of people to one another in the spaces they occupy mindfully and physically:

... when you go space closes over like water behind you, Do not look back: there is nothing outside you, space is only time visible in a different way, places we love we can never leave (Lalic, 1996).

\section{Compassion, lounging love and the infinity between us}

Jane Pujji (2007) wonders 'would we regret too many busy days and not enough lounging love?' Michael O'Siadhail (1992) says, 'always this love, this infinity between us'. While this is a reflection on the importance and power of intimate relationships it also warns that passion and interdependence are easily lost sight of in the 'busyness' of life. As social workers we need to find and preserve the intensity of passion and compassion that is central to social justice. The fabric of society relies on inclusion and an explicit acceptance that we're all in this together. James Wright (1961) catches this sense of oneness in A Blessing:

Just off the highway to Rochester Minnesota, twilight bounds softly forth on the grass. And the eyes of the two Indian ponies darken with kindness. They have come gladly out of the darkness to welcome my friend and me. We step over the barbed wire into the pasture where they have been grazing all day alone. They ripple tensely they can hardly contain their happiness that we have come.

This is a wonderful image of the soul-full power of reciprocity that takes us beyond a casual and superficial understanding of relatedness.

Compassion requires more than just having empathy for another though.

Before you know what kindness really is you must lose things, feel the future dissolve in a moment like salt in a weakened broth. What you held in your hand, what you counted and carefully saved, all this must go so you know how desolate the landscape can be between the regions of kindness (Naomi Shihab Nye, 1995).

Compassion as a core element of social justice requires action based on an understanding that something is not right or unfair, and that the scales of justice need tipping. Frequently for social workers the acting out of social justice occurs through things like advocacy or social action.

Advocacy is an aspect of social work that is heavily promoted as contributing to social justice. Successful advocacy leaves clients better off and alters balances of power. Usually this is in relation to the client's material well-being or conflicting situation with a social control organisation or system. There is however a dimension of creativity in advocacy that is part of social work as an art. This creative dimension is the element of not accepting or putting 
aside what exists, and then working to create a new form or different state. While there is usually a clear focal point to advocacy it does require commitment and to some extent a leap of faith. The time and effort involved can be significant and relies on perseverance, patience, and passion. 'How far could you swim daddy in such a storm? 'As far as was needed,' I said, and as I talked I swam' (William Stafford, 1977). W.S. Merwin (1983) identifies 'the great presence that permitted everything and transmuted it was passion, passion was genius and he praised movement and invention.'

Working creatively for change also takes time, 'when so much forgetting is about remembering on the long walk backwards ... inside the long history of goodbye' (Harlow, 2009b).

\section{Mindfulness}

Being creative and using imagination has an established place in the social work craft. The process of critically reflective practice enables this by creating an openness and receptiveness to the unknown as we bring together what we know with what we sense through intuition. The mindfulness that results is a pathway to inspiration and hope. Poetry has much to say on such matters.

A note waterfalls steadily through us just below hearing. Or this early light streaming through dusty glass: what enters, enters like that, unstoppable gift. And yet there is also the other, the breath space held between any call and its answer ... the rest note, unwritten, hinged between worlds, that precedes change and allows it (Jane Hirshfield, 1994).

It's not easy to escape the past ... the future, barring variations turns out to be not so different from the present where we have always lived - the same struggle of wishes and losses, and hope, the old lieutenant, picking us up every so often to dust us off and adjust our helmets. Adjustment, for that matter may be the one lesson hope has to give, serving us best when we begin to find what we didn't know we wanted in what the future brings (Wesley McNair, 2003).

Like a lot of familiar everyday things and places, it is easy to overlook or take for granted the intricacy and richness that surrounds us. We can be side-tracked by important issues while overlooking issues of essence and being. As workers it is also easy to overlook the true character of those we work with, or our own character for that matter.

Whether we understand it or not, the thin space between hope and despair is our profession's ordinary workplace. As identified at the start of the article, Mindfulness should propel us into the extraordinary that is 'in things' (Nemerov, 1977). Mindfulness enables us to see beyond where 'the mold of emptiness stoutly swaggers' (Rilke, 1995, The Tenth Duino Elegy) in our clients. 'The essence of critically reflective practice is responsiveness to the perspective and aspirations of the client' (Beddoe 2004). Mary Oliver (1986) reminds us:

... you do not have to be good, you do not have to walk on your knees for a hundred miles through the desert repenting ... the world offers itself to your imagination, calls to you like the wild geese, harsh and exciting - over and over announcing your place in the family of things. 
Maintaining a soulful and mindful approach to our work is challenging.

\section{Curiosity, light, and the 'furthest simplicities' (Nemerov, 1977)}

Much of what we deal with in social work is complex and convoluted. Often, however, society at large through the media approaches complexity through sound bites, partial stories and stereotypes. Regrettably agencies, funders and political drivers tend to also ignore the complexity in the rush to fix, control or contain. There is dislike of the notion that taking time might be an important factor or that most stories have as many aspects and dimensions as a labyrinth. One of the duties of social work is to improve understanding and fight discrimination and indifference. This often requires deconstruction of complexity artfully through assessment, analysis, and reflection until the simple appears. This is not straightforward and relies on curiosity and readiness to use uncommon sense through the passage of time. I think it is also important to explore dualisms and the concepts of light and dark as part of recognising the spiritual make up of our lives.

Nemerov (1977) describes how this reaching simplicity occurs in great art:

And hence the careless crowd deludes itself by likening his hieroglyphic signs And secret alphabets to the drawing of a child. That likeness is significant the other side of what they see, for his simplicities are not the first ones, but the furthest ones, final refinements of his thought made visible.

Nemerov moves from this to the idea of looking beyond things, but most importantly to the 'shining of happiness through darkest themes' and 'they imitate the light that is in thought, for the mind relates to thinking as the eye relates to light'.

At one level this reflects the spark of hope and the idea that we sometimes have to experience rock bottom before things can get better. In the usual way of spirals however, the concept of 'shining of happiness through darkest themes' contains the depth of an essential and eternal paradox, that of dark and light occurring together. An extension of this is the notion of the things that are beyond us which grow out of the core of our being in unexpected ways.

Most social workers will have experienced situations where someone who is a seemingly 'nice' person has done terrible things. Frequently too we see people who have nothing or who are in exceptionally difficult situations act with exceptional generosity of spirit or heroically towards others. Analysis, assessment, and conventional theory may provide explanations for these variations of being human. Equally there is the aspect of soul or spirit that we shouldn't ignore.

A poetic lens can help make us curious about these dimensions of spirit and soul, complex and simple, light and dark. At the least a poetic lens will add to our mindfulness and help us wonder about mystery.

\section{Bringing art and science together poetically}

The harsher realities social workers deal with can invoke a cynical view over time. Similarly 
the push to evidence and scientific discourses constrain and deride intuitive and humanistic influences, yet the call to justice and inclusion requires continual curiosity and wonder. As R.S. Thomas (1993) writes in Gift. 'Some ask the world and are diminished in the receiving of it. You gave me only this small pool, that the more I drink from, the more overflows with ceaseless light.'

Harms and Connolly (2009) argue the exercise of professional judgement is the hallmark of effective practice and demands creativity, reflection, integration of knowledge about what works, and practice wisdom gained through experience. They conclude personal and professional development become more integrated and better connected through critical reflection, reflexivity and practice. Practice science relates to knowledge and practice art is the way theories are used in the amalgam of the practitioner's developmental space and the client situation.

The poetics of social work allow the less apparent and mysterious spiritual dimensions of the worker, the client and the situation to come into play. The poetics contribute to reflexivity and self-evolution in the exercise of professional judgement while also giving hope full momentum. In my field of management I frequently use poems in public addresses and staff and management workshops. My experience is that poetry provides an imaginative pathway into and out of complex matters. It frees people to laugh, cry, sit up, be attentive, or just be in different ways. It shifts heart, mind and soul. In the words of Central Otago poet Brian Turner (2009) 'Cloud - roamer, dreamer, when you feel some part of you is flying you know you're one with the best you'll be.'

\section{Conclusion}

Nemerov remembers the artist Paul Klee as the 'Painter dreaming in the Scholar's House'. The concepts and depth conveyed are just as applicable to social work:

... and when impatience in the street and still despair at home, divide the mind to rule it, there shall be some comfort come ... his dream an emblem to us of the life of thought, the same dream that then flared before intelligence when light first went forth looking for the eye.

When we are faced with despair, abuse and injustice, finding courage, and acting with integrity of heart and mind, gives hope to us and those we work with.

The poetics of social work provide a framework 'where eternity of thought opens upon perspective time and space' (Nemerov, 1977). In this opening, the space we seek with clients, 'stealing like the tide across the map' (Lowell, 1977), should also aim to draw others into clients' lives in an enduring way. Carver's (1996) poem Late Fragment captures this evocatively: '... and did you get what you wanted from this life even so? I did. And what did you want? To call myself beloved, to feel myself beloved on this earth'.

To enable this connectedness requires mindfulness, and acceptance that social work practice is an art involving poetics through the creative use of mystery, imagination, and faith in action. Longfellow (2003) leaves us with a taste of artful reflection and action with these words: 'Let us then be up and doing with a heart for any fate, still achieving, still pursuing, learn to labour and to wait'. 


\section{References}

Andrews, G. (2004). The cure. In G. Keillor (Selected and introduced by), Good poems for hard times (p 115). New York: Penguin Books.

Beddoe, L. (2004). Reflection in and critical reflection on social work: Learning about learning and thinking about thinking in social work. Social Work Review XVI, 4, 50-57.

Bly, R. (1981). For my son Noah, ten years old. In G. Keillor (Selected and introduced by), Good poems for hard times (p. 33). New York: Penguin Books.

Carver, R. (1996). Late fragment. In N. Astley (Ed.) Staying alive (p. 456). New York: Miramax Books.

Collins, W. (1998). Shovelling snow with Buddha. In R. Housden (Ed.) 110 poems of love and revelation (pp. 11, 12). New York: Harmony Books.

Crane, H. (1933). Voyages II. In R. Bly, J. Hillman, \& M. Mead (Eds.). The rag and bone shop of the heart (pp. 444-445). New York: Harper Perennial.

Dowrick, S. (2009). In the company of Rilke. NSW: Allen \& Unwin.

Harlow, M. (1985) Pensioners. Vlaminck's Tie (p. 45). New Zealand: Auckland University Press.

Harlow, M. (2005). I am a Tyger. Cassandra's Daughter (p. 39). New Zealand: Auckland University Press.

Harlow, M. (2009a). All about the world. The tram conductors blue cap (p. 5). Auckland: Auckland University Press.

Harlow, M. (2009b). The longest day of the year. The tram conductor's blue cap (p. 35). Auckland: Auckland University Press.

Harms, L., \& Connolly, M. (2009) The art and science of social work. In Social work contexts and practice, (2nd ed.) (chapter 1, pp. 3-18). Victoria: Oxford University Press.

Hirshfield, J. (1994). The door. In R. Housden (Ed.) 110 poems of love and revelation (p. 131). New York: Harmony Books.

Jacottett, P. (1987). Distances. In N. Astley (Ed.) Staying alive (p. 267). New York: Miramax Books.

Lalic, I. (1996). Places we love. In N. Astley (Ed.) Staying alive (p. 424). New York: Miramax Books.

Longfellow, H. (2003). The psalm of life. Sourced August 1st 2011 from http:/ / www.poemhunter.com/ poem/thepsalm-of-life. Create date January 13th 2003.

Lowell, R. (1977). Epilogue. In N. Astley (Ed.). Staying alive (p. 453). New York: Miramax Books.

McNair, W. (2003). The future. In G. Keillor (Selected and introduced by). Good poems for hard times (pp. 177,178). New York: Penguin Books.

Machado, A. (1983). Portrait. In R. Bly, J. Hillman, \& M. Mead (Eds.). The rag and bone shop of the heart (pp. 374-375). New York: Harper Perennial.

Maidment, J. \& Egan, R. (2004). (Eds) Practice skills in social work and welfare. More than just common sense. New South Wales: Allen and Unwin.

Merwin, W. S. (1983). Berryman. In G. Keillor (Selected and introduced by). Good poems for hard times (pp. 164,165). New York: Penguin Books.

Milner, V. (2006). Uncommonly sensible social work practice: Using depths of conventional wisdom and spirituality to match what we know with what we sense. Social Work Review Volume, XVIII(3), 61-68.

Nemerov, H. (1977). The painter dreaming in the scholar's house. In N. Astley (Ed.) Staying alive (pp. 450-453). New York: Miramax Books.

Nye, N.S. (1995). Kindness. In R. Housden (Ed.) 110 poems of love and revelation (pp. 76, 77). New York: Harmony Books.

Oliver, M. (1986). Wild geese. In N. Astley (Ed.) Staying alive (p. 5). New York: Miramax Books.

O'Siadhail, M. (1992). Between. In N. Astley (Ed.) Staying alive (p. 290). New York: Miramax Books.

Pujji, J. (2007). I was wondering. Follow yourself home: Word remedies to heal and inspire (p. 204). New Zealand: The Living Well Publications.

Rilke, R. M. (1981a). Just as the winged energy of delight. In R. Bly, J. Hillman, \& M. Mead (Eds.). The rag and bone shop of the heart (p. 236). New York: Harper Perennial.

Rilke, R. M. (1981b). A walk. In R. Bly, J. Hillman, \& M. Mead (Eds.). The rag and bone shop of the heart (p. 423). New York: Harper Perennial.

Rilke, R. M. (1995). The tenth duino elegy. In N. Astley (Ed.) Staying alive. (p. 44). New York: Miramax Books.

Sodergran, E. (1981). On foot I had to walk through the solar systems. In R. Housden (Ed.) 110 poems of love and revelation (p. 25). New York: Harmony Books.

Stafford, W. (1977). A ritual to read to each other. In R. Bly, J. Hillman, \& M. Mead (Eds.). The rag and bone shop of the heart (p. 233). New York: Harper Perennial.

Stafford, W. (1977). With Kit, age 7, at the beach. In R. Bly, J. Hillman, \& M. Mead (Eds.). The rag and bone shop of the heart (p. 37). New York: Harper Perennial.

Thomas, R. S. (1993). In R. Housden (Ed.). In R. Housden (Ed.) 110 poems of love and revelation (p. 129). New York: Harmony Books.

Turner, B. (2009). A wry big bloke. Just this (pp. 51-53). Wellington: Victoria University Press.

Wright, J. (1961). A blessing. In R. Bly, J. Hillman, \& M. Mead (Eds.). The rag and bone shop of the heart (p. 435). New York: Harper Perennial. 